Z. klin. Chem. u. klin. Biochem.

8. Jg., S. 9-11, Januar 1970

\title{
The Specific Property of Paraprotein Lipids in Serum Concerning the Heparin Clearing Effect
}

\author{
By Mira Keler-Bačora \\ Department of Medicine, University Hospital Zagreb, Rebro, Jugoslavija
}

(Eingegangen am 30. Juni 1969)

The heparin clearing test was performed on 12 patients with $\beta$-, $\gamma$-plasmocytoma paraproteins respectively, and on one patient with Macroglobulinaemia Waldenstroem while 7 healthy persons served as controls.

Serum turbidity, total fat concentrations, one-dimensional electrophoresis of lipids and proteins were determined in the sera before and after i. v. application of $12500 \mathrm{I}$. U. of heparin.

After the administration of heparin, all plasmocytoma and Macroglobulinaemia paraprotein, as well as the control sera, showed the serum turbidity clearing effect, the decrease of total fats and the acceleration of the electrophoretic mobilities of the $\alpha$ - and $\beta$ lipoproteins.

Contrary to this, the plasmocytoma $\beta$-, $\gamma$ - and Macroglobulin-paraprotcin lipids showed specific behaviour in the post-heparin sera: they were resistant to the heparin acceleration effect and migrated before and after heparin administration with the same electrophoretic mobility as the corresponding paraproteins.

This permits a clear separation of the serum paraprotein lipid component from the $\beta$-lipoproteins in post-heparin sera and can be of use in the diagnosis of $\beta$ - and $\gamma$-plasmocytomas and of Macroglobulinaemia Waldenstroem respectively.

Der Heparin-Klärungs-Test wurde an 12 Patienten mit $\beta$-bzw. $\gamma$-Plasmocytom-Paraproteinen und einen Patienten mit Makroglobulinämie Waldenstroem durchgeführt. Als Kontrollen dienten 7 gesunde Probanden.

Vor und nach i. v. Applikation von 12500 I. E. Heparin wurden Trübung des Serums und Gesamt-Lipidkonzentration im Serum bestimmt sowie Lipid- und Protein-Elektrophorese durchgeführt.

Nach Heparingabe zeigten alle Plasmacytom- und Makroglobulinämie-Paraprotein- ebenso wie die Kontrollseren eine Klärung der Serumtrübung, Abfall der Serumlipide und schnellere Wanderung $\operatorname{der} \alpha$ - und $\beta$-Lipoprotcine in der Elektrophorese.

Im Gegensatz dazu zeigen Plasmacytom- $\beta$ - und $\gamma$ - und Makroglobulinämie-Paraprotein-Lipide im Postheparin-Serum ein spezifisches Verhalten: Sie zeigen keinen Heparin-Effekt und wandern vor und nach Heparingabe mit der gleichen elektrophoretischen Geschwindigkeit wie die entsprechenden Paraproteine.

Dieser Befund gestattet in Postheparin-Serum eine klare Trennung von Paraprotein-Lipid-Komponenten und $\beta$-Lipoproteinen und kann für die Diagnose von $\beta$ - und $\gamma$-Plasmocytom sowie Makroglobinämie Waldenstroem von Nutzen sein.

The lipid electrophoresis of sera from patients suffering from plasmocytoma reveals a significant lipid component associated with the $\beta$ - and $\gamma$-paraproteins or macroglobulins (1). Although this paraprotein lipid component has the same electrophoretic mobility as the $\beta$ lipoproteins (i. e., it migrates in the region of the $\beta$ - and $\gamma$-globulins in paper electrophoresis), it may be characterised by certain specific properties that distinguish it from the $\beta$-lipoproteins: paraprotein lipids cannot be precipitated from serum with polyanions such as dextran sulphate (2) or heparin (3); they do not form complexes with dextran in colloidal solution (4); they behave differently in two dimensional lipid electrochromatography (5).

The i. v. administration of heparin in hyperlipemia is known to clarify the serum turbidity, to decrease the serum fat concentration and to acceletate the $\operatorname{serum} \alpha-$ and $\beta$-lipoproteins on the paper lipidogram (6).

Because of the similar electrophoretic mobilities of $\beta$ lipoproteins and the lipid component of $\beta$ - and $\gamma$-paraproteins (the region of the $\beta$-and $\gamma$-globulins), studies were made in this paper on the possible effect of the i.v. administration of heparin on the mobility of paraprotein lipid components in one dimensional paper strip lipid electrophoresis.

\section{Materials and methods}

The heparin clearing test was performed on 12 patients with $\beta$ - and $\gamma$-plasmocytoma respectively and on one patient with marcroglobulinaemia Waldenstroem, while 7 healthy persons served as controls.

The examined persons were loaded with a fat breakfast $(200 \mathrm{ml}$ of cream and $50 \mathrm{~g}$ of butter). Blood was drawn in the fasting state and in maximal resorption of fats i. e. $3.30 \mathrm{~h}$ after the breakfast. Then $12500 \mathrm{I}$. U. of heparin in solution were administered i. $\mathbf{v}$. and blood samples were taken 30 and 60 minutes after heparin application.

Serum turbidity and total fat concentration (7) were determined in the fasting sera and in all the samples taken in the mentioned intervals $(0 \mathrm{~h}, 3.30 \mathrm{~h}, 4.00 \mathrm{~h}, 4.30 \mathrm{~h})$.

Serum lipids and proteins were analyzed simultaneously by onedimensional paper strip electrophoresis on Whatman filter paper No. 1 in phosphate buffer $\mathrm{pH} 8.6$ at $3-4 \mathrm{~V} / \mathrm{cm}$ for 18 hours. The lipids and proteins on the electrophoresis paper strip were stained with Sudan black B and Bromphenol blue solutions respectively.

\section{Experiments and results}

The results of serum turbidity, of total fat concentrations, of protein electrophoresis and of total proteins in the fasting sera, in lipaemia and after loading with heparin are represented on table 1.

The table shows that, following the fatty breakfast, the turbidity and total fat concentration are more or less 
Table 1

Turbidity, Fat Concentration and Protein Electrophoresis in Serum before and after Administration of 12500 I. U. of Heparin

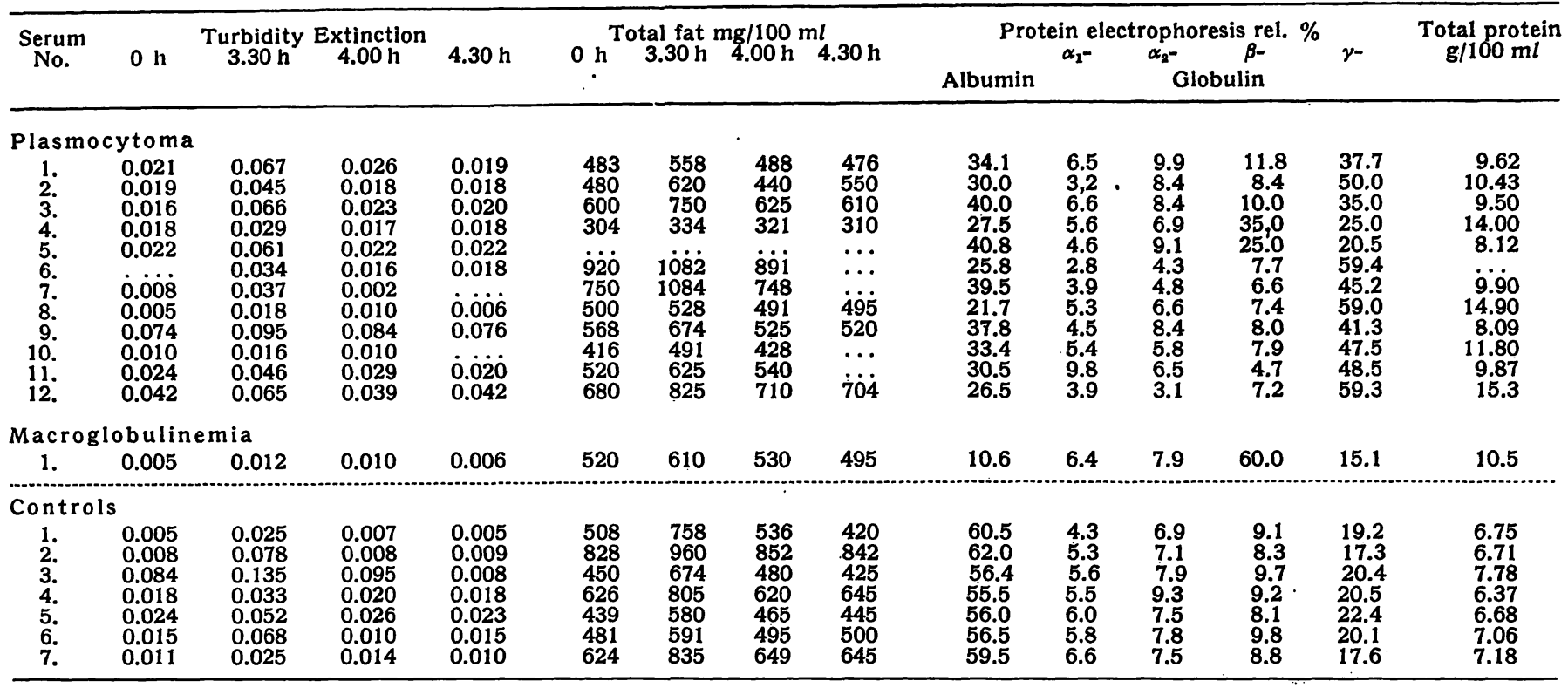

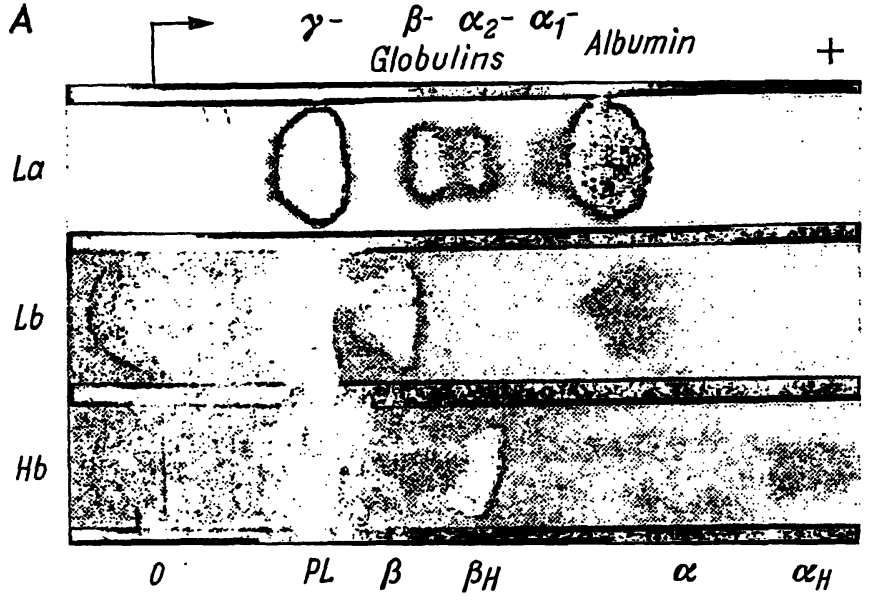

$B$
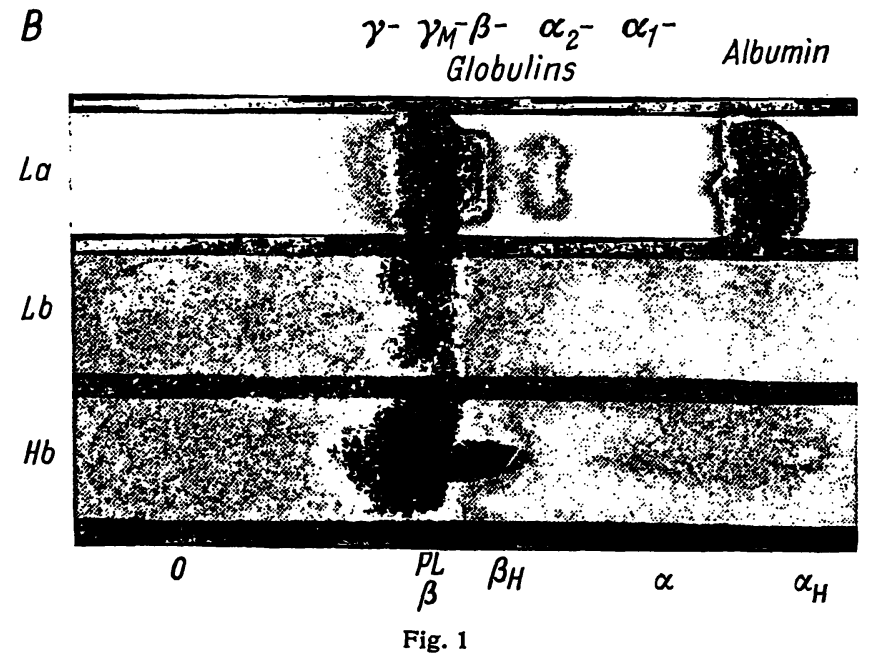

One-Dimensional Paper Electrophoresis of Paraprotein Sera before and after Application of 12500 I. U. Heparin Solution

A. $\gamma$-paraprotein serum; B. Macroglobulinaemia Waldenstroem serum

$\mathrm{L} a=$ lipaemia, protein staining

$\mathrm{Hb}=$ post-heparin serum, lipid staining

$O=$ neutral fats

$\mathrm{PL}=$ paraprotein lipid component

$\beta=\beta$-lipo protein

$\beta_{\mathrm{H}}=\beta$-lipo protein lipid in post-heparin serum

$\alpha_{H}=\alpha$-lipo protein-lipid in post-heparin serum increased in the plasmocytoma, in the mactoglobulinaemia paraprotein sera and in the control sera. Some of the hyperlipaemic paraprotein sera showed only a slight turbidity and fat increase, caused by the less intensive resorption of fats in the plasmocytoma patients. The serum turbidity clearing effect and the decrease of total fat following the administration of heparin was proved as reported by other authors (6).

The clearing effect of heparin examined by lipid electrophoresis was found to be accompanied by the acceleration of the electrophoretic mobilities of the $\alpha$ - and $\beta$-lipoproteins in all examined post-heparin sera.

Contrary to this the plasmocytoma $\beta$-and $\gamma$-paraprotein lipid and the Macroglobulin paraprotein lipid components demonstrated in all the post-heparin sera a specific behaviour: although migrating in the region of the normally present $\beta$-lipoproteins (region of $\beta$ - and $\gamma$-globulins), they were resistant to the heparin acceleration effect and migrated before and after heparin administration with the same electrophoretic mobilities i. e. with the mobility of the corresponding paraproteins.

This phenomenon is evident from figure 1 , where two of the experiments performed with $\gamma$-paraprotein and macroglobulin sera are represented. On the lipidograms of the lipaemic serum $(A, L b)$ with gamma-paraproteins $(\mathrm{A}, \mathrm{La})$ the paraprotein lipid is clearly differentiated from the $\beta$-lipoproteins. On the corresponding serum lipidogram after heparin administration $(A, H b)$ the acceleration of the $\alpha_{\mathrm{H}^{-}}$and the $\beta$-lipoproteins $\left(\beta_{\mathrm{H}}\right)$ is evident, as well as the unchanged electrophoretic mobility of the paraprotein lipid.

The lipidogram of lipaemic Macroglobulinemia serum $(B, L b)$ demonstrates a case where the paraprotein lipid macroglobulin component is overlapping the usually occurring $\beta$-lipoproteins. Contrary to this on the postheparin serum $(B, H b)$ lipidogram the accelerated 
$\beta$-lipoproteins $\left(\beta_{\mathbf{H}}\right)$ are clearly separated from the paraprotein lipid fraction whose position remained unchanged by the application of heparin.

This specific behaviour of the paraproteins lipid component, which is resistant to the accelerating effect of heparin, permits a clear separation of the paraprotein lipid components from the $\beta$-lipoproteins in post-heparin plasmas and can be used in the diagnosis of $\beta$ - and $\gamma$-plasmocytomas and of Macroglobulinaemia Waldenstroem respectively.

\section{Discussion}

This paper describes a new specific property of the lipid component of serum $\beta$-, $\gamma$ - and macroglobulin paraproteins, which migrate in one-dimensional paper electrophoresis with the same mobility as the serum $\beta$-lipoproteins. Unlike the serum $\beta$-lipoproteins, which are accelerated with heparin, the paraprotein lipid fraction is found to be resistant to the acceleration effect of heparin and migrates before and after the i. v. administration of this compound with the same electrophoretic mobility as the serum paraproteins.

Previously we described some other specific properties of the paraprotein lipid component in sera from patients with plasmocytomas, which all differ from the properties of serum $\beta$-lipoproteins : unlike to the $\beta$-lipoproteins, which are completely precipitated with dextran sulphate or heparin $(8,9)$, the paraprotein lipids cannot be precipitated from the serum with these compounds $(2,3)$; unlike the $\beta$-lipoproteins, which are complexed with colloidal dextran (10), the paraprotein lipid fractions are not able to form complexes with colloidal dextran solution (4); the two-dimensional electrochromatographic effect of the paraprotein lipid fractions is also different from the electrochromatographic effect of $\beta$-lipoproteins (5).

These earlier published findings $(2,3,4,5)$, in addition to the specific behaviour of the paraprotein lipid components presented here show that the paraprotein lipid components differ from the $\beta$-lipoproteins in a number of different physical and chemical properties. The lipid component of the paraprotein molecule seems to be firmly bound to the paraprotein molecule (5) and cannot be dissociated from the paraprotein to interact with other compounds $(2,3,4)$.

Hiermit möchte ich der Technikerin JosIPA FranjKović für die wertvolle technische Mitarbeit danken.

\section{Refererences}

1. SACHS, B. A., P. CADY and G. Ross, Amer. J. Med. 17, 662 (1954). - 2. Keler-BA ̌ookA, M., Clin. chim. Acta Amsterdam 8, 215 (1963). - 3. Keler-BAčoka, M., Clin. chim. Acta Amsterdam 16, 365 (1967). - 4. Keler-BAČOKA, M., Experientia Basel 21, 338 (1965). - 5. Kelerr-Bacoka, M., Z. Pǔ̌ar and M. Petek, Clin. chim. Acta Amsterdam 3, 335 (1958). - 6. Harn, P. F.,
Science Washington 98, 19 (1943). - 7. Farstad, M., Clin. chim. Acta Amsterdam 14, 341 (1966). - 8. Burstern, M. and J. SAmallle, Clin. chim. Acta Amsterdam 3, 320 (1958). - 9. Burstein, M. and J. Samaille, Clin. chim. Acta Amsterdam 5, 609 (1960). - 10. PuČAR, Z. and M. KELER-BA čoKA, Science Washington 134,1369 (1961).
Doc. Dr. Mira Keler-Baćoka Interna Klinika Medicinskog Fakulteta Zagreb, Rebro Jugoslavija 